\title{
Ecofriendly Wood Adhesives from Date Palm Fronds Lignin for Plywood
}

\author{
Hiba Ibrahim Huzyan, Alia Abdul Aziz, and M. Hazwan Hussin * \\ Utilization of lignin phenol glyoxal (LPG) resins was studied as a potential \\ alternative for phenol formaldehyde (PF) resins. Lignin was extracted by \\ alkaline pulping processes (kraft and soda) from date palm fronds (DPF) \\ and was used as an alternative for phenol in LPG resins. The isolated \\ lignin samples were characterized using complementary analyses that \\ included Fourier transform infrared (FTIR) spectroscopy, ${ }^{13} \mathrm{C}$ nuclear \\ magnetic resonance (NMR) spectroscopy, thermal stability, thermogravi- \\ metric analysis (TGA), and differential scanning calorimetry (DSC). Kraft \\ lignin phenol glyoxal (KLPG) and soda lignin phenol glyoxal (SLPG) resins \\ also were characterized in terms of solid content, viscosity, and gel time. \\ Finally, physico-mechanical tests were performed on plywood panels that \\ were treated with different molar ratios of LPG resins. The results revealed \\ that $50 \%(\mathrm{w} / \mathrm{w}) \mathrm{KLPG}$ resin resulted in higher tensile strength (65.3 MPa) \\ than PF resin (58.57 MPa), which was potentially attributed to the higher \\ amount of phenolic groups compared to soda lignin. Therefore, the \\ substitution of DPF lignin in LPG resins enhanced the adhesive in terms \\ of its chemical and mechanical properties, enabling it to produce a more \\ environmentally friendly wood adhesive.
}

Keywords: Lignin; Wood adhesive; Date palm fronds

Contact information: Materials Technology Research Group (MaTReC), School of Chemical Sciences, Universiti Sains Malaysia, 11800 Minden, Penang, Malaysia;

*Corresponding author:mhh@usm.my;mhh.usm@gmail.com

\section{INTRODUCTION}

Phenolic resins are credited as the oldest synthetic thermosetting polymers. Due to their outstanding chemical and mechanical properties and characteristics, i.e., high water resistance, dimensional and thermal stability, chemical resistance, and electrical insulation, they are widely applied as acid-resistant coatings, fiber-reinforced composites, electric laminates, and in wood industrial production of exterior-grade plywood panels, oriented strand board panels, and particleboards (Danielson and Simonson 1998; Ramires et al. 2010; Foyer et al. 2016b). However, the toxicity of formaldehyde (McGregor et al. 2006) and the potential shortage of phenol production from the non-renewable petrochemical resources have triggered researchers to conduct numerous studies to investigate possible alternative ecofriendly substances as a replacement to petroleum-based materials in phenol formaldehyde resins (Wu 1997; Ibrahim et al. 2011). Some of the bio-based polymers that have been used are proteins, tannins, lignin, and polysaccharides (Ballerini et al. 2005; Moubarik et al. 2015; Hussin et al. 2017).

Lignin is known as a complex phenolic polymer that is built up by oxidative coupling of three major phenylpropanoid units, namely trans-para-coumaryl alcohol, trans-coniferyl alcohol, and trans-sinapyl alcohol. Thus, it is characterized by having a high aromatic density and high cross-linked structure that is comparable to phenol network 
structure (Ibrahim et al. 2007). The functional groups in unmodified lignin are mainly aliphatic and aromatic hydroxyl groups, and methoxyl groups, of which the phenolic $-\mathrm{OH}$ groups play a main role in substitution reactions. The structure similarity between phenol and lignin renders the condensation reaction between phenol and formaldehyde in phenolic resins the same as the condensation reaction between lignin and glyoxal in lignin phenol glyoxal resins (Younesi-Kordkheili and Pizzi 2019). Currently, lignin has been isolated from different lignocellulosic waste and exploited in phenol-formaldehyde adhesives as a phenol substituent, due to the structural similarity of both polymers (Zhang et al. 2013).

One of the types of lignocellulosic biomass that lignin could be isolated from is date palm fronds. Date palm trees (Phoenix dactylifera) are widely cultivated across Northern Africa and the Middle East and are naturalized in many tropical and subtropical regions worldwide. Analysis of date palm trees showed a low to medium hemicelluloses content ( $13 \%$ to $31 \%$ ), cellulose (33\% to $48 \%$ ), a high ash content (1\% to $15 \%$ ), and extractives ( $8 \%$ to $33 \%$ ) comparing to other lignocellulosic materials, and a moderate lignin amount (26\% to $40 \%$ ). More specifically, date palm fronds presented $26 \%$ of lignin, which is similar to those found in other wood species and non-wood plants (Nasser et al. 2016). The reasonable lignin content in the fronds, the increasing amount of waste from the date palm trees that can reach $40 \mathrm{~kg}$ (most of them are leaves and surface fibers around the trunk) in a country like UAE (Mallaki and Fatehi 2014), were the reason behind choosing the date palm fronds as a lignin source.

Furthermore, formaldehyde is regarded as carcinogenic by the International Agency for Research on Cancer (IARC) and the Scientific Committee on Occupational Exposure Limits (SCOEL) (IARC 2006). Thus, to produce an environmentally friendly wood adhesive, formaldehyde can be fully replaced by hexamine, glyoxal, and furanic materials (i.e., furfural and furfuryl alcohol) (Norström et al. 2014; Foyer et al. 2016a; Santiago-Medina et al. 2016; Hussin et al. 2019). Glyoxal is considered as a non-toxic aldehyde, which is non-volatile, biodegradable, and has a low cost. In addition, it could react with lignin in a similar way to the condensation of formaldehyde with lignin (Faris et al. 2017). Many studies have investigated bio-based wood adhesives by producing ligninphenol-glyoxal resins (Hussin et al. 2019; Younesi-Kordkheili 2019). Younesi-Kordkheili (2019) used ionic liquid treated lignin in the preparation of lignin phenol glyoxal adhesive to bond particleboard panels, which demonstrated mechanical properties in par with panels treated with phenol formaldehyde resins. As well, Hussin et al. (2019) obtained lignin from kenaf core (Hibiscus cannabinus), and partially substituted phenol in lignin-phenol-glyoxal adhesives. It was a 3:7 ratio of lignin to phenol in lignin-phenol-glyoxal resins that gave the highest internal bonding $(53.83 \mathrm{MPa})$ and tensile strength $(72.08 \mathrm{MPa})$ compared to that of phenol formaldehyde resin.

There have been a great number of studies regarding lignin and glyoxal utilization in wood adhesives, including the study of the preparation kraft lignin phenol glyoxal (KLPG) and soda lignin phenol glyoxal (SLPG) adhesives. However, to the best of our knowledge, the adhesives were not modified by date palm fronds lignin. In this paper, lignin was extracted from date palm fronds by the use of alkaline pulping processes (kraft and soda). Subsequently, kraft lignin (KL) and soda lignin (SL) were used to prepare both adhesives, kraft lignin phenol glyoxal and also soda lignin phenol glyoxal adhesives. Complementary analyses, Fourier transform infrared (FTIR), ${ }^{13} \mathrm{C}$ nuclear magnetic resonance (NMR), thermogravimetric analysis (TGA), and differential scanning calorimetry (DSC) were done to characterize KL and SL. Additionally, LPG adhesives' mechanical properties were studied and compared to phenol formaldehyde adhesives. 


\section{EXPERIMENTAL}

\section{Materials}

The fronds of the date palm tree were sourced from Abu Dhabi, UAE in December 2018. The fronds were cut, ground, and sieved to get a fine powder. The utilized chemicals were glacial acetic acid (99.8\%), formaldehyde (37\%), sodium hydroxide (97\%), sulphuric acid (98\%), ethanol (99.7\%), hydrochloric acid (37\% v/v), and toluene (grade AR). These were procured from QReC, Rawang, Malaysia. Phenol (99.5\%) and sodium sulphide (95\%) were gained from R\&M Chemical, Essex, UK. Acetic anhydride ( $\geq 98.5 \%)$ and glyoxal (40\% wt\% solution in water) were purchased from Merck, Darmstadt, Germany. Chloroform (99.8\%) and tetrahydrofuran $(99.99 \%)$ were purchased from Fisher Chemicals, Loughborough, UK. Sodium chlorite $(80 \%)$ pure was purchased from Acros Organics, Morris Plains, NJ, USA. Pyridine ( $\geq 99.5 \%$ ) was purchased from Bendosen, KL, Malaysia. Finally, distilled water was used in the study.

The proximate analysis for DPF was performed according to Laboratory Analytical Procedure (LAP), TAPPI T203 cm-09 (2009), and TAPPI T222 om-02 (2006), to analyze the DPF $(\% \mathrm{w} / \mathrm{w})$ components in terms of the content of moisture which was $8.36 \pm 0.55 \%$, the content of ash $3.28 \pm 0.82 \%$, extractives content $0.9 \pm 0.18 \%$, cellulose $41 \pm 1.00 \%$, hemicellulose $22.8 \pm 1.2 \%$, and Klason lignin $24 \pm 0.01 \%$.

\section{Kraft and Soda Lignin Extraction}

The alkaline pulping processes were conducted in a $1.0-\mathrm{L}$ high pressure reactor. The conditions for soda and kraft pulping followed the work of Hussin et al. (2013) with minor adjustments. The conditions used in kraft pulping were as follows: $70 \%$ of active alkali and $30 \%$ sulfidity. These were added to a solid to liquid ratio of $1: 10$ at $150{ }^{\circ} \mathrm{C}$ for 4 h. While in soda lignin pulping, 30\% (w/v) of $\mathrm{NaOH}$ was used with the similar ratio, temperature, and time as kraft pulping. The pressure in both pulping processes was around 10 bar. To recover the black liquor, vacuum filtration was performed; then, $20 \%$ (v/v) sulphuric acid was used to acidify the liquor until it reached $\mathrm{pH} 2$ to precipitate soda and kraft lignin (Ibrahim et al. 2011) The mixture was centrifuged for 20 min for further precipitation. Afterward, lignin precipitate was dried in a $50{ }^{\circ} \mathrm{C}$ oven overnight to be recovered. Lignin was added to $\mathrm{pH} 2$ water for further separation of hemicellulose, then filtered and dried. Lignin yield was calculated using Eq. 1:

$$
\% \text { Yield }=\frac{\text { weight of lignin recovered }(g)}{\text { weight of } D P F(g)} \times 100 \%
$$

\section{Adhesive Preparation}

According to Hussin et al. (2018), Phenol was substituted by lignin using different percentages. The adhesive preparation method and the amounts of chemicals used were as follows; phenol formaldehyde and phenol glyoxal that contain $0 \mathrm{wt} \%$ of lignin were prepared as control adhesives. Meanwhile, 10, 30, and 50\% wt $\%$ of phenol were substituted by both KL and SL in lignin phenol glyoxal resins. Lignin, phenol, $\mathrm{NaOH}$, and ethanol amounts are summarized in Table 1. Glyoxal to phenol (G/P) molar ratio was 1.5:1.0. Ethanol was introduced as a solvent, while $\mathrm{NaOH}$ was added as a catalyst in the amount of $5 \mathrm{wt} \%$ of phenol. The mixture of lignin/formaldehyde, phenol, $\mathrm{NaOH}$, and ethanol was heated under reflux with constant stirring until it reached $80^{\circ} \mathrm{C}$. Then the glyoxal was

Huzyan et al. (2021). "Palm fronds lignin adhesive," BioResources 16(2), 4106-4125. 
introduced to the refluxed mixture (dropwise). The refluxed time was $2 \mathrm{~h}$. After that, a rotary evaporation for the resin was performed to get rid of the excess ethanol.

Table 1. Composition Used in Resinification of Lignin Samples

\begin{tabular}{|c|c|c|c|c|c|c|}
\hline Resin & $\begin{array}{c}\text { Lignin } \\
(\mathrm{g})\end{array}$ & Phenol $(\mathrm{g})$ & $\begin{array}{c}\text { Glyoxal } \\
(\mathrm{mL})\end{array}$ & $\begin{array}{c}\mathrm{NaOH} \\
(\mathrm{g})\end{array}$ & $\begin{array}{c}\text { Ethanol } \\
(\mathrm{mL})\end{array}$ & $\begin{array}{c}\text { Formaldehyde } \\
(\mathrm{mL})\end{array}$ \\
\hline PG & - & 27.46 & 50 & 1.58 & 100 & - \\
\hline PF & - & 31.53 & - & 1.58 & 100 & 50 \\
\hline $10 \%$ KLPG & 2.746 & 24.71 & 50 & 1.58 & 100 & - \\
\hline $30 \%$ KLPG & 8.23 & 19.22 & 50 & 1.58 & 100 & - \\
\hline $50 \%$ KLPG & 13.73 & 13.73 & 50 & 1.58 & 100 & - \\
\hline $10 \%$ SLPG & 2.74 & 24.71 & 50 & 1.58 & 100 & - \\
\hline $30 \%$ SLPG & 8.23 & 19.22 & 50 & 1.58 & 100 & - \\
\hline $50 \%$ SLPG & 13.73 & 13.73 & 50 & 1.58 & 100 & - \\
\hline
\end{tabular}

\section{Characterizations}

\section{FTIR spectroscopy analysis}

The FTIR analysis was conducted for KL, SL, and the solid adhesives using PerkinElmer System 2000 FTIR spectrometer (Waltham, MA, USA). The range of wavenumber used was from 4000 to $400 \mathrm{~cm}^{-1}$ and the number of scans was 20 . Potassium bromide disc technique was performed in the preparation of samples with 1:100 ratio.

\section{${ }^{13}$ C NMR spectroscopy analysis}

The $150 \mathrm{mg}$ acetylated samples of KL and SL were dissolved in a $0.4 \mathrm{~mL}$ d6-DMSO with slight heating until it completely dissolved. This was used to perform ${ }^{13} \mathrm{C}$ analysis using Bruker Avance 500 NMR spectrometer (Fallanden, Switzerland) at 12000 scans at room temperature. The Bruker Top Spin software (v.3.5, Oxford, UK) was utilized to obtain and interpret the spectra.

\section{$T G A$}

The KL, SL, and the solid adhesives' thermal performance were studied using PerkinElmer TGA model STA 8000 (Waltham, MA, USA), the range of temperature was (30 to $900{ }^{\circ} \mathrm{C}$ ) in the nitrogen atmosphere.

\section{$D S C$}

The KL and SL samples' glass transition temperature $\left(T_{\mathrm{g}}\right)$ was investigated via DSC analysis. The analysis was controlled with a heating rate of $20^{\circ} \mathrm{C} \mathrm{min}-1$, from 0 to $300{ }^{\circ} \mathrm{C}$ then cooling to $0{ }^{\circ} \mathrm{C}$. The DSC analysis was conducted using a Q200 Differential Scanning Calorimeter from TA Instruments (New castle, DE, USA) in the School of Industrial Technology.

\section{Physicochemical tests}

The resins' physicochemical properties were tested in terms of solid content, viscosity, and gel time. The resins' viscosity was obtained using Brookfield DVII+Viscometer (Middleborough, MA, USA), spindle No. 5 with $100 \mathrm{rpm}$ at room temperature. The recorded viscosity was in Pascal-second (Pa-s) units (Hussin et al. 2018) For the solid content determination, around $1.0 \mathrm{~g}$ of each resin was placed in a petri dish, which was placed in $105^{\circ} \mathrm{C}$ oven for $24 \mathrm{~h}$ as the standard method of TAPPI T650 cm-15 (2015). The nonvolatile content was determined using Eq. 2: 


$$
\% \text { Solid content }=\frac{\text { Final weight }}{\text { Initial weight }} \times 100 \%
$$

Additionally, the resins' gel time was determined by placing approximately $1.5 \mathrm{~g}$ of each resin in a 17-mm test tube. Then, the tube was heated in an oil bath at $140{ }^{\circ} \mathrm{C}$. The resins were stirred with a helical copper coil until gelation. The gel time was recorded in seconds (s) (Hussin et al. 2018).

\section{Curing of LPG Adhesives to Plywood}

Resins were spread over three layers of veneer wood and pressed two times in a hot-press machine (Carver, Wabash, IN, USA). First, each specimen was pressed at room temperature for $7 \mathrm{~min}$. Second, the wood panels were pressed at $140{ }^{\circ} \mathrm{C}$ for another $7 \mathrm{~min}$. The pressure used in both pressing times was $1.4479 \times 10^{7} \mathrm{~Pa}$. The pressing method was in accordance with the Japanese Industrial Standards, JIS- A 5908 (2003). Particleboards.

\section{Mechanical Test}

For the mechanical performance of the wood adhesives, the wood panels were cut in the dimensions of $12.0 \mathrm{~cm} \times 2.0 \mathrm{~cm} \times 0.6 \mathrm{~cm}$. The tensile strength test was conducted in dry condition. The test was conducted using Instron UTM 5582 (Instron, Norwood, MA, USA) in the School of Industrial Technology, USM (Malaysia).

\section{RESULTS AND DISCUSSION}

Table 2 summarizes the proximate and elemental analyses results of lignin. The results showed that the soda lignin had a higher yield than the kraft lignin as a result of the higher severity of the reaction conditions. The presence of nitrogen in each lignin was probably because of the amino acid (protein building blocks) base of forming the monolignols and the crosslinking of lignin to hemicellulose via a cell wall protein (Horwath 2015). Thus, as nitrogen is a component of amino acids, a trace amount will be present in lignin. The presence of protein attached to lignin in a small amount proposes the stable chemical bond that is hard to break despite acid precipitation, as many studies previously have revealed (Hussin et al. 2013).

Table 2. Proximate Analysis of Kraft and Soda Lignin from Date Palm Fronds

\begin{tabular}{|c|c|c|}
\hline & Kraft Lignin & Soda Lignin \\
\hline Yield (\%) & $17 \pm 0.2$ & $21 \pm 0.1$ \\
\hline Element (\%) & & 57.48 \\
\hline Carbon & 62.47 & 5.06 \\
\hline Hydrogen & 4.62 & 0.51 \\
\hline Nitrogen & 0.52 & 36.95 \\
\hline Oxygen & 32.39 & 5.28 \\
\hline $\begin{array}{c}\text { Double Bond Equivalent } \\
\text { (DBE) }\end{array}$ & 6.03 & \\
\hline
\end{tabular}

\section{FTIR Analysis}

Date palm fronds' KL and SL FTIR spectra are represented in Fig. 1. The spectra showed the characteristic bands for syringyl (S) and guaiacyl $(\mathrm{G})$ in the region of 1450 to $800 \mathrm{~cm}^{-1}$. 


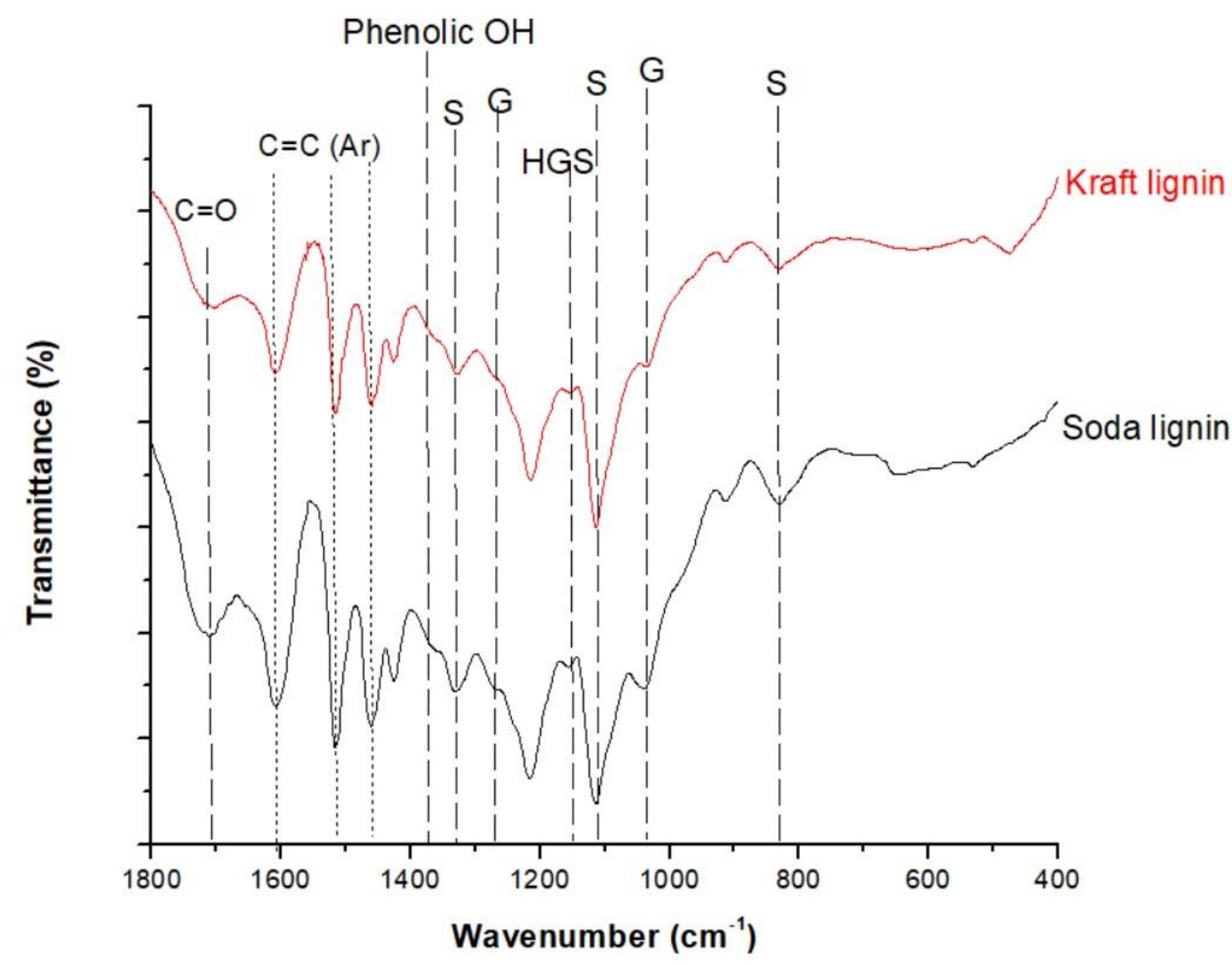

Fig. 1. FTIR spectra of the expanded spectrum between 1800 to $400 \mathrm{~cm}^{-1}$ for DPF lignin

Table 3. Assignment of FTIR Spectra for Date Palm Fronds Lignin

\begin{tabular}{|c|c|c|}
\hline Assignment & Kraft Lignin & Soda Lignin \\
\hline & \multicolumn{2}{|c|}{ Band Location $\left(\mathrm{cm}^{-1}\right)$} \\
\hline $\mathrm{O}-\mathrm{H}$ (phenolic and aliphatic) stretching & 3414 & 3405 \\
\hline $\mathrm{C}-\mathrm{H}$ stretching ( $\mathrm{CH} 3$ and $\mathrm{CH} 2$ groups) & 2939 & 2937 \\
\hline $\mathrm{C}-\mathrm{H}$ stretching $(\mathrm{OCH} 3)$ & 2851 & 2847 \\
\hline $\begin{array}{c}\mathrm{C}=\mathrm{O} \text { stretching (unconjugated ketone, carbonyl, and } \\
\text { ester groups) }\end{array}$ & 1715 & 1714 \\
\hline $\mathrm{C}=\mathrm{C}$ stretching (aromatic skeleton) & 1610,1516 & 1612,1518 \\
\hline $\mathrm{C}-\mathrm{H}$ deformation (asymmetric in $-\mathrm{CH}_{3}$ and $-\mathrm{CH}_{2}$ ) & 1463 & 1463 \\
\hline $\begin{array}{c}\text { C-C stretching (aromatic skeleton) with } \mathrm{C}-\mathrm{H} \text { in plane } \\
\text { deformation }\end{array}$ & 1427 & 1426 \\
\hline C-O stretching (syringyl) & 1331 & 1334 \\
\hline $\mathrm{O}-\mathrm{H}$ (phenolic) In-plane deformation vibration & 1365 & 1365 \\
\hline C-O stretching vibration of secondary alcohol & 1275 & 1273 \\
\hline $\begin{array}{c}\mathrm{C}-\mathrm{O}(\mathrm{H})+\mathrm{C}-\mathrm{O}(\mathrm{Ar}) \begin{array}{l}\text { (phenolic } \mathrm{OH} \text { and ether in syringyl } \\
\text { and guaiacyl) }\end{array} \\
\end{array}$ & 1216 & 1217 \\
\hline $\mathrm{Ar}-\mathrm{CH}$ in plane deformation (syringyl) & 1116 & 1114 \\
\hline $\mathrm{C}-\mathrm{O}(\mathrm{H})+\mathrm{C}-\mathrm{O}(\mathrm{C})$ (first order aliphatic $\mathrm{OH}$ and ether & 1064 & 1044 \\
\hline $\mathrm{C}-\mathrm{H}$ out of plane (aromatic ring) & 953 & 918 \\
\hline $\mathrm{C}-\mathrm{H}$ out of plane (aromatic ring) & 835 & 829 \\
\hline
\end{tabular}


Table 3 represents the assignments of the corresponding bands. Both lignin samples showed low absorbance intensity for G bands $\left(\sim 1044\right.$ and $\left.1273 \mathrm{~cm}^{-1}\right)$ and modest to high absorbance intensity for $\mathrm{S}$ bands $\left(\sim 830,1115\right.$, and $\left.1330 \mathrm{~cm}^{-1}\right)$, which suggests higher syringyl content in lignin. It is believed that different pulping process will give different absorbance intensity (Thring et al. 1990). The $\mathrm{S}$ bands appeared as less intense peaks in KL than SL owing to the demethoxylation during the kraft pulping process (Nadji et al. 2009; Hussin et al. 2013). The severe conditions of kraft pulping process converts Stype units into more stable G-type units. According to the FTIR spectra, the results confirmed the presence of potential active sites for lignin polymerization due to the presence of G-type units.

\section{${ }^{13} \mathrm{C}$ NMR Analysis}

The ${ }^{13} \mathrm{C}$ NMR characterization was performed for further investigation of the isolated lignin structures. Figure 2 illustrates the ${ }^{13} \mathrm{C}$ NMR spectra for the acetylated KL and SL. The KL and SL samples were introduced into acetylation process according to Váquez-Torres et al. (1992), to improve their solubility in organic solvents. Acetyl groups became as a substituent to all the hydroxyl functional groups via the acetylation reaction. The region between 104 to 154 ppm represented the signals of S, G, and p-hydroxyphenyl (H) units (Fig. 2b) as follows; 104 ppm (C2/C6,S), 139 ppm (C4,S), 152 ppm (C3/C5, S etherified), $148.5 \mathrm{ppm}$ (C3/C5,S non-etherified), $114 \mathrm{ppm}(\mathrm{C} 2, \mathrm{G}), 116 \mathrm{ppm}$ (C5,G), 120 ppm (C6,G), 134 ppm (C1,G etherified), 145 ppm (C3,G non-etherified), and 127.4 ppm is for (C2/C6, p-coumaric acid ester). The aliphatic esters and aliphatic carboxyls appeared around $170 \mathrm{ppm}$, relating to lignin oxidation during alkaline pulping (Sun et al. 2012). While the strong signal at $56.5 \mathrm{ppm}$ represented the methoxyl group in both the $\mathrm{S}$ and $\mathrm{G}$ units.

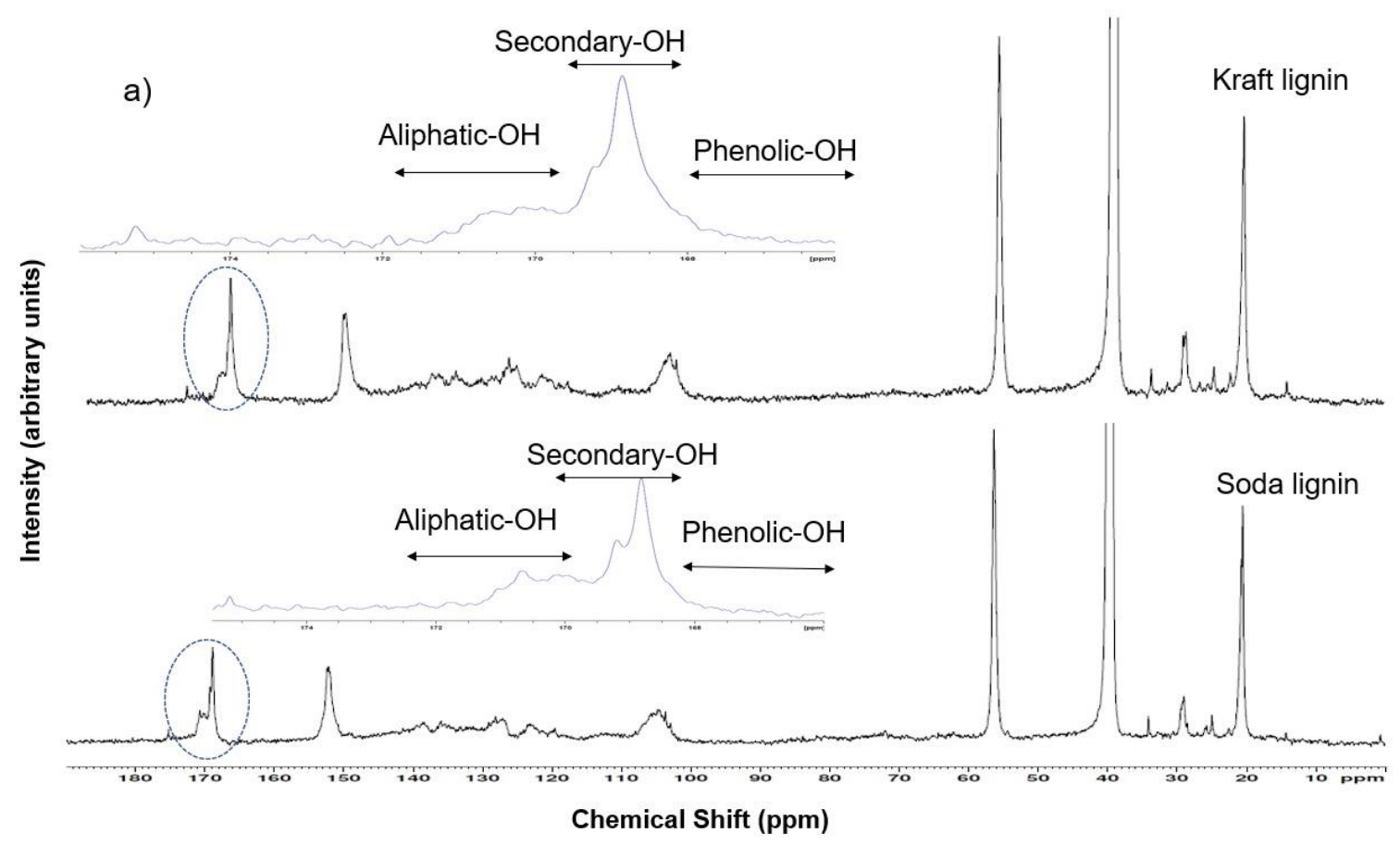




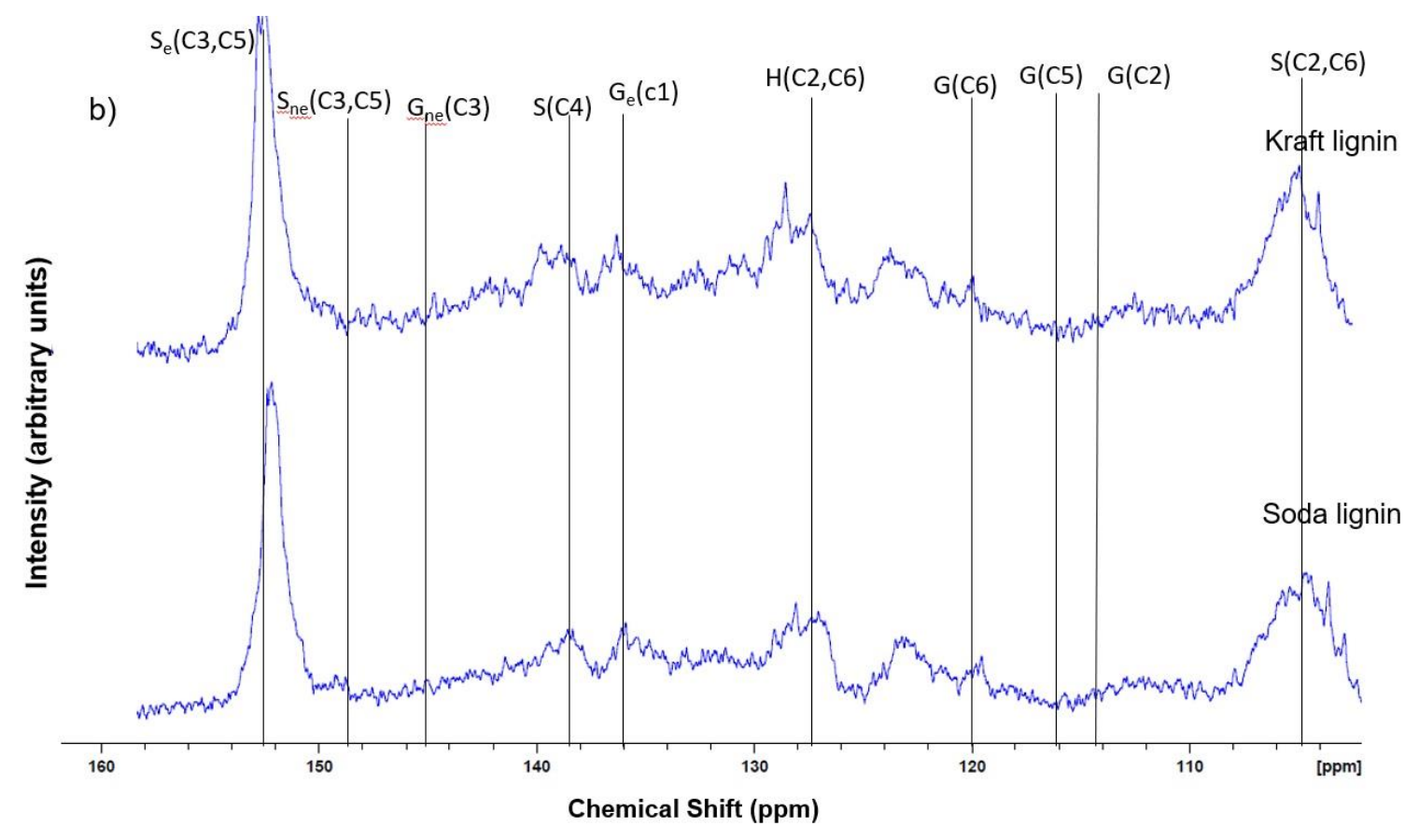

Fig. 2. ${ }^{13} \mathrm{C}$ NMR spectra of (a) acetylated DPF lignin with (b) expanded aromatic region; H: phydroxyphenyl unit; G: guaiacyl unit; S: syringyl unit; e: etherified; ne: non etherified

The integral region of 162 to $102 \mathrm{ppm}$ was established as a reference, as the presumption is that it consists of six aromatic carbons and 0.12 vinylic carbons. Thus, the integral values in that region were divided by 6.12 to be equivalent to one aromatic ring (Ar), with the aim of studying the quantity of each hydroxyl groups per one aromatic ring (Capanema et al. 2004).

Table 4 shows the region between 172 to $166 \mathrm{ppm}$, in which KL had higher phenolic-OH amount (1.4/Ar) than SL (0.9/Ar). Furthermore, the quantity of secondary$\mathrm{OH}$ in $\mathrm{KL}$ was 2.0/Ar, which was higher than SL (1.6/Ar). Meanwhile, the quantity of aliphatic-OH was almost constant for KL (1.3/Ar) and SL (1.4/Ar). It was clear that the ratio of aromatic to aliphatic hydroxyls was alike for both KL and SL, due to the effect of the pulping method: kraft pulping generates phenolic-OH through the bond of aryl-ether cleavage in DPF and lignin depolymerization, while soda pulping eliminates aliphatic-OH (Tejado et al. 2007). Thus, that explains the higher phenolic-OH amount in KL, which leads to a higher amount of aromatic ring positions for the cross-linking with glyoxal through the resinification process.

Table 4. Comparison of the Hydroxyl and Methoxy Groups Amount Between Acetylated Kraft and Soda Lignin from Date Palm Fronds

\begin{tabular}{|c|c|c|c|}
\hline Range (ppm) & Assignment & \multicolumn{2}{|c|}{ Amount (Per Aromatic) } \\
\hline & & Kraft Lignin & Soda Lignin \\
\hline 172 to 169.6 & Aliphatic-OH & 1.3 & 1.4 \\
\hline 169.6 to 168.6 & Secondary-OH & 2.0 & 1.6 \\
\hline 168.6 to 166 & Phenolic-OH & 1.4 & 0.9 \\
\hline 58 to 54 & $\begin{array}{c}\text { Methoxy group } \\
\left(-\mathrm{OCH}_{3}\right)\end{array}$ & 4.7 & 4.6 \\
\hline
\end{tabular}




\section{Thermal Analysis}

$T G A$

Thermogravimetric study was conducted to investigate the thermal behavior of DPF lignin. Figure 3 (a and b) illustrated the thermogravimetric (TG) and differential thermogravimetric (DTG) curves of KL and SL, respectively. The curves show that the range of thermal degradation temperature was between 100 and $900{ }^{\circ} \mathrm{C}$.

It can be seen from Fig. 3a that, around $53{ }^{\circ} \mathrm{C}$, a weight loss for both lignin samples occurred due to attached and absorbed water evaporation that generates carbon dioxide and methane, side unsaturated chains, and carbon monoxide (Hoareau et al. 2004). The next phase of weight loss was around 209 to $243{ }^{\circ} \mathrm{C}$ due to degradation of carbohydrates. Xylose degrades when the temperature increased from 200 to $270{ }^{\circ} \mathrm{C}$ (Sahoo et al. 2011). In addition, it was found by García et al. (2009) that the attached hemicellulose to lignin degrades at 200 to $300{ }^{\circ} \mathrm{C}$.

Above $300{ }^{\circ} \mathrm{C}$, lignin structures started to degrade, mainly through the cleavage of methyl-aryl ether bonds that liberated water and formaldehyde (Sun et al. 2000; Tejado et al. 2007) until the maximum rate of weight loss (DTG $\mathrm{Dmax}_{\text {) }}$ at $375^{\circ} \mathrm{C}$ and $381{ }^{\circ} \mathrm{C}$ for $\mathrm{KL}$ and SL, respectively (Fig. 3b).

It was noticed that SL had higher thermal degradation compared to KL as the temperature was raised from 380 to $450{ }^{\circ} \mathrm{C}$, which could be due to a high purity and large number of $-\mathrm{OCH}_{3}$ groups (Sahoo et al. 2011). The DPF lignin was compared to lignin from oil palm empty fruit bunch (Ibrahim et al. 2011) and from corn cob (Ibrahim et al. 2010), DTGmax around $347^{\circ} \mathrm{C}$ and $352^{\circ} \mathrm{C}$, respectively.

The DPF lignin has higher DTG $_{\max }$, indicating a higher thermal stability and higher cross-linking. The non-volatile components for KL and SL were $61 \%$ and $51 \%$, respectively. The higher residue for KL revealed that it has a higher content of inorganic material, probably form the addition of sodium sulphide in kraft pulping process (Hussin et al. 2019).

The narrow curve in Fig. 3b for both lignin samples suggested a high cross-linked structure and more C-C interlinked bonds (Hussin et al. 2013). This result was also supported by the high residue percentages for both lignin samples. The thermal analysis results showed that KL and SL samples from DPF were steady at elevated temperature, which reveals a high branching degree and high condensed aromatic structure.

\section{$D S C$}

The DSC study was conducted to correlate glass transition temperature $\left(T_{\mathrm{g}}\right)$ to the molecular weight of lignin samples. The result showed that SL's $T_{\mathrm{g}}$ value was $40.4{ }^{\circ} \mathrm{C}$, which was greater than KL's $T_{\mathrm{g}}$ value $\left(T_{\mathrm{g}}=36.57^{\circ} \mathrm{C}\right)$. Theoretically, the $T_{\mathrm{g}}$ value describes the ability of the main chain of the polymer to rotate in terms of the obtained energy. At first, the chains in the lignin molecule received energy to vibrate, then to rotate as it receives more energy.

As a result, $T_{\mathrm{g}}$ can be correlated to the molecular weight based on the free volume in the molecule (Thring et al. 1991). In this case, SL had higher molecular weight, which suggests that it had few chain ends that lead to a low volume movement that entails further energy to pivot the chain and higher $T_{\mathrm{g}}$ value (Ibrahim et al. 2011). 

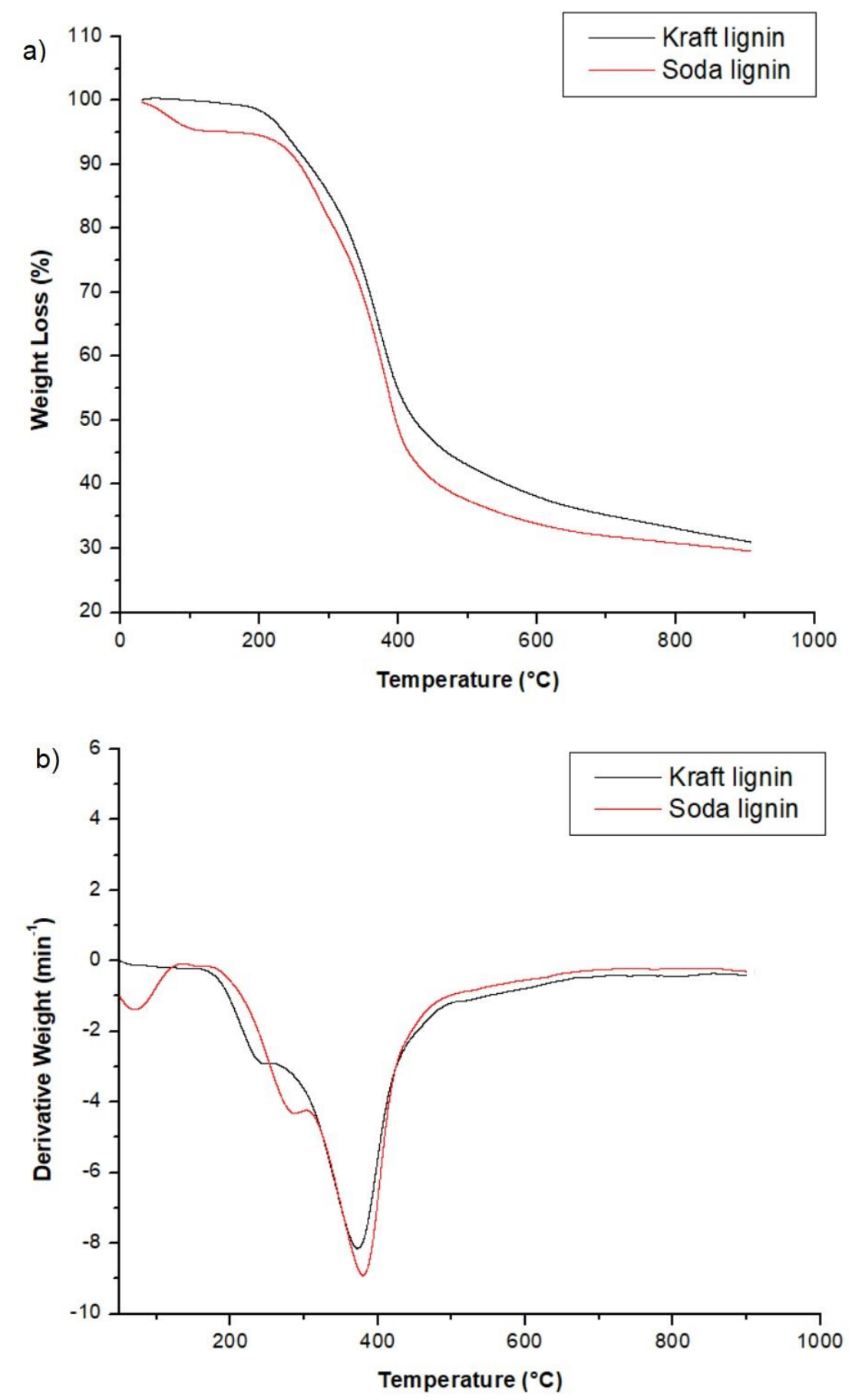

Fig. 3. a) TG and b) DTG curves of DPF lignin

\section{Characterization of Wood Adhesives}

Table 5 shows the solid content, viscosity, and gel time for LPG resins, PG, and PF resins. The results for solid content showed an increment as the phenol percent substitution with lignin increased. The substitution of 50\% KPLG had the highest solid content $50 \%$ KLPG: $40 \%$ ) but PG resins with zero lignin substitution had the lowest solid content percentage (PG: 23.5\%). As for SLPG resins, it showed the same trend for solid content (10\% SLPG: $32.0<30 \%$ SLPG: $35.5 \%<50 \%$ SLPG: $37.0 \%$ ). 
Table 5. Solid Content, Viscosity, and Gel Time for Control Resins (Phenol Formaldehyde (PF) and Phenol Glyoxal (PG)), Soda Lignin Phenol Glyoxal (SLPG), and Kraft Lignin Phenol Glyoxal (KLPG)

\begin{tabular}{|c|c|c|c|}
\hline Resin & Solid Content (\%) & Viscosity (Pa-s) & Gel Time (s) \\
\hline PF & 60.0 & $0.192 \pm 1.5$ & 100 \\
\hline PG & 23.5 & $0.036 \pm 4.0$ & 660 \\
\hline $10 \%$ SLPG & & & 295 \\
\hline $30 \%$ SLPG & 32.0 & $0.045 \pm 2.3$ & 231 \\
\hline $50 \%$ SLPG & 35.5 & $0.091 \pm 3.0$ & 150 \\
\hline $10 \%$ KLPG & 37.0 & $0.110 \pm 5.0$ & 280 \\
\hline $30 \%$ KLPG & 31.0 & & 240 \\
\hline $50 \%$ KLPG & 36.0 & $0.046 \pm 2.3$ & 140 \\
\hline
\end{tabular}

Note: Solid content is the nonvolatile content of the resin, viscosity is the thickness of the resin, gel time is the time it takes for a resin to become so highly viscous

In the same way, the increase in lignin substitution increased the viscosity value for LPG adhesives. In this study, as the amount of lignin increased from $10 \%$ to 50\% in KLPG, the viscosity surged from 0.046 to 0.165 Pa-s. The same trend was seen in SLPG viscosity values compared to PG resin (PG: 0.036 Pa-s < 10\% SLPG: 0.045 Pa-s < 30\% SLPG: 0.091 Pa-s < 50\% SLPG: $0.106 \mathrm{~Pa}-\mathrm{s}$ ). It was believed that the viscosity would indicate the degree of condensation; therefore, the higher amount of lignin will contribute to a higher amount of depolymerized lignin. This would cause the elongation of the polymeric chains or additional branching within the structure of LPG resins, which would improve their density. The resins' high density prevents their mobility and triggers rapid freezing when exposed to air (Ibrahim et al. 2007; Monni et al. 2007).

The gel time correlates with viscosity and solid content; therefore, the increase in phenol substitution amount results in faster resin gelation. The shortest gel time presented by 50\% KLPG at $149 \mathrm{~s}$ compared to $660 \mathrm{~s}$ for PG (zero lignin). This result can be ascribed to the higher viscosity and solid content of 50\% KLPG, which indicates its higher degree of condensation (Siddiqui 2013).

The FTIR spectra of PG, 50\% SLPG, and 50\% KLPG adhesives are shown in Fig. 4; the corresponding band assignments are summarized in Table 6 . The results presented similar trends compared to former studies (Aziz et al. 2019; Hussin et al. 2019). The band at $1467 \mathrm{~cm}^{-1}$ represents the $\mathrm{C}-\mathrm{H}$ deformation in the $-\mathrm{CH}_{2}$ bridge in 50\% KLPG and SLPG. It indicates the formulation of the connection between lignin and phenol glyoxal in the resins. Other peaks have increased or appeared after the condensation reaction, such as the band $\sim 1047 \mathrm{~cm}^{-1}$ that corresponded to C-O stretching vibration of first order aliphatic $\mathrm{OH}$, $\mathrm{C}-\mathrm{O}$ (methylol) and ether, which does not appear in PG spectra. The band located at $\sim 1200$ $\mathrm{cm}^{-1}$ was attributed to $\mathrm{C}-\mathrm{C}, \mathrm{C}-\mathrm{O}$, and $\mathrm{C}=\mathrm{O}$ stretching vibration as a result of introducing glyoxal into lignin structure through the condensation procedure (El Mansouri et al. 2011). The C-O stretching in phenolic $\mathrm{OH}$ and ether in $\mathrm{S}$ and $\mathrm{G}$ type is represented by the peak $1218 \mathrm{~cm}^{-1}$. According to the resins' FTIR spectra, the presence of G-type units and phenolic hydroxyl groups in LPG make it suitable to form a lignin-based wood adhesive. 


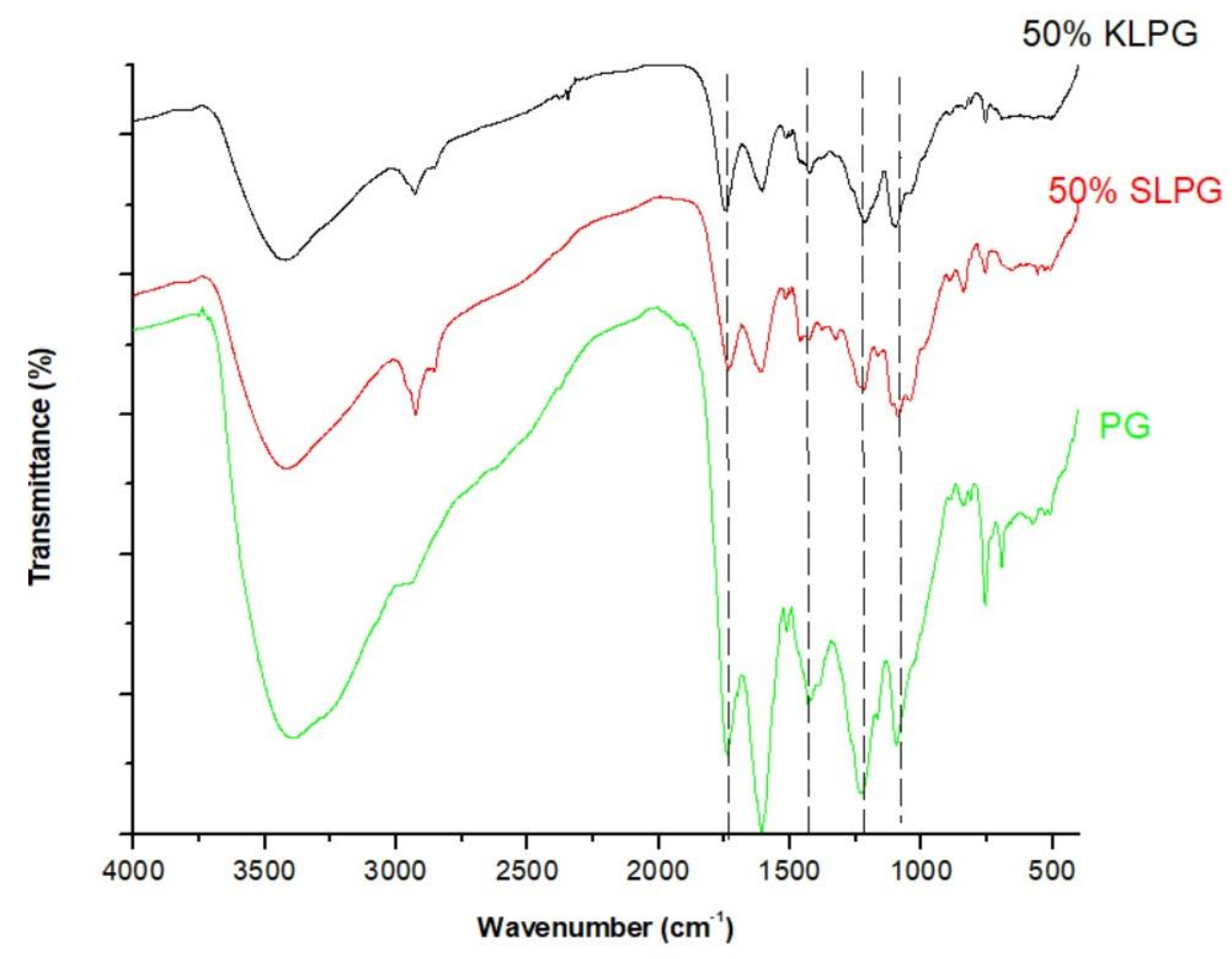

Fig. 4. FTIR spectra of KLPG, SLPG, and PG

Table 6. Band Assignment for FTIR Spectra of PG, KLPG, and SLPG Resins

\begin{tabular}{|c|c|c|c|}
\hline Assignments & $P G$ & KLPG & SLPG \\
\hline & \multicolumn{2}{|c|}{ Wavenumber $\left(\mathrm{cm}^{-1}\right)$} & \\
\hline $\mathrm{OH}$ stretching vibration & 3425 & 3440 & 3439 \\
\hline Asymmetric $\mathrm{CH} 2$ vibration & 2961 & 2930 & 2929 \\
\hline $\begin{array}{c}\mathrm{C}=\mathrm{O} \text { stretching of } \\
\text { aldehyde/ketone groups }\end{array}$ & 1741 & 1751 & 1734 \\
\hline $\begin{array}{c}\mathrm{C}=\mathrm{C} \text { stretching vibration in } \\
\text { benzene ring }\end{array}$ & 1613 & 1611 & 1617 \\
\hline $\begin{array}{l}\mathrm{C}-\mathrm{H} \text { deformation mode in } \mathrm{CH}_{2} \\
\text { groups }\left(-\mathrm{CH}_{2} \text { bridge }\right)\end{array}$ & - & 1467 & 1467 \\
\hline $\begin{array}{l}\text { C-C stretching (aromatic } \\
\text { skeleton) with } \mathrm{C}-\mathrm{H} \text { in plane } \\
\text { deformation }\end{array}$ & 1400 & - & - \\
\hline C-O stretching (syringyl) & - & 1342 & 1335 \\
\hline $\begin{array}{c}\mathrm{C}-\mathrm{O}(\mathrm{H})+\mathrm{C}-\mathrm{O}(\mathrm{Ar}) \text { (phenolic } \\
\mathrm{OH} \text { and ether in syringyl and } \\
\text { guaicyl }\end{array}$ & 1238 & 1218 & 1223 \\
\hline $\begin{array}{l}\mathrm{C}-\mathrm{O}(\mathrm{H})+\mathrm{C}-\mathrm{O}(\mathrm{C}) \text { (first order } \\
\text { aliphatic } \mathrm{OH} \text { and ether) }\end{array}$ & - & 1043 & 1047 \\
\hline $\mathrm{C}-\mathrm{H}$ out of plane (aromatic) & 849 & 836 & 846 \\
\hline $\begin{array}{l}\text { C-H out of plane, para- } \\
\text { substituted }\end{array}$ & 833 & 816 & 825 \\
\hline $\begin{array}{l}\text { C-H out of plane, ortho- } \\
\text { substituted }\end{array}$ & 760 & 757 & 763 \\
\hline Adjacent 5H & 695 & 697 & 669 \\
\hline
\end{tabular}


The ${ }^{13} \mathrm{C}$ NMR spectra (Fig. 5) showed noticeable peaks that resulted from the lignin phenol glyoxal resinification process. Mainly, the methylol group peak $\left(-\mathrm{CH}_{2} \mathrm{OH}\right)$ appeared at $64 \mathrm{ppm}$. This correlated with the benzyl alcohol group that was produced due to glyoxalation and attached to the ortho site of the aromatic ring. As a result, a quinone methide and a phenoxy group also formed and showed a peak at around 174 and $158 \mathrm{ppm}$, respectively (Mansouri et al. 2007). The peaks that correspond to phenolic-OH disappeared as a result of introducing the hydroxymethyl groups on $\mathrm{C} 3$ and $\mathrm{C} 5$ positions in the aromatic ring of lignin, which was supported by the appearance of methylol peaks. A signal around $57 \mathrm{ppm}$ illustrated the shift of the carbon on the methoxy group $\left(-\mathrm{OCH}_{3}\right)$, which was attributed to $\mathrm{G}$ and $\mathrm{S}$ units in kraft and soda lignin. Moreover, the peak at around $90 \mathrm{ppm}$ corresponded to glyoxal oligomers. The region between 130 and $110 \mathrm{ppm}$ represented the substituted ortho and para carbon positions on the aromatic ring (Trosa and Pizzi 1998). The aromatic carbons peaks demonstrate the polymerization of lignin and phenol, which could give the intense peaks at aromatic position.

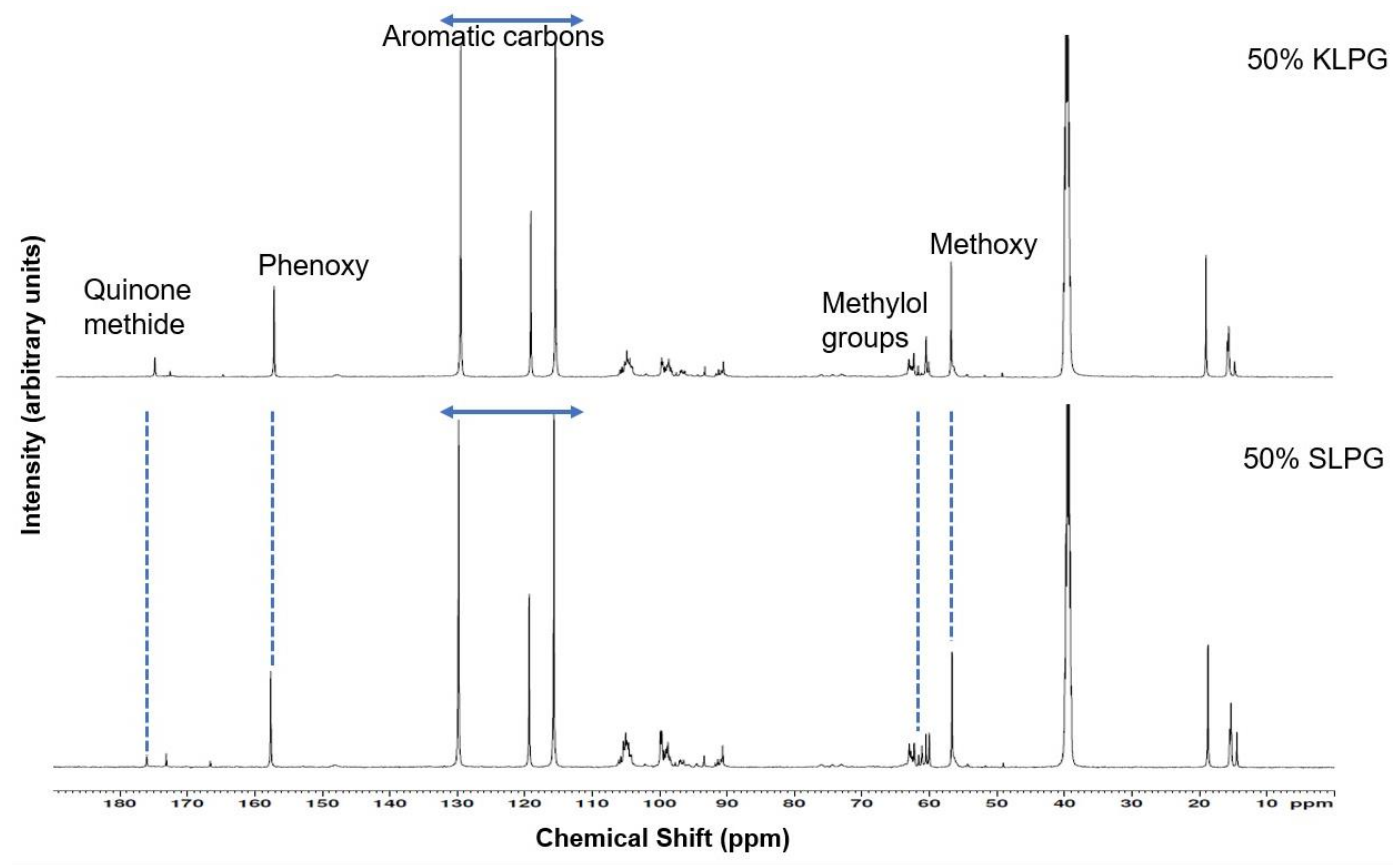

Fig. 5. ${ }^{3} \mathrm{C}$ NMR spectra of $50 \%$ KLPG and $50 \%$ SLPG adhesives

The thermal behavior of LPG and PG resins was investigated by TGA analysis. The results were compared to previous studies, and most of the lignocellulosic materials showed the same trend (Ramires et al. 2010; Wang et al. 2018; Hussin et al. 2019). From the curves (Fig. 6), a slight weight loss was observed below $120{ }^{\circ} \mathrm{C}$ as a result of free water evaporation and other small volatile molecules. Between 200 and $300{ }^{\circ} \mathrm{C}$, the weight loss was due to the water evaporation, glyoxal, and phenol - which were founded as a result of the condensation of methylol groups - were observed due to evaporation. Additionally, the water that was established by the condensation of the methylene groups and the phenolic$\mathrm{OH}$ caused the weight loss at around 350 to $450{ }^{\circ} \mathrm{C}$. The last thermal degradation between 450 and $600{ }^{\circ} \mathrm{C}$ was due to the loss of carbon monoxide and methane that were found by the reaction between water and the hydrogen with methylene groups, respectively (Trick and Saliba 1995; Lenghaus et al. 2001). 

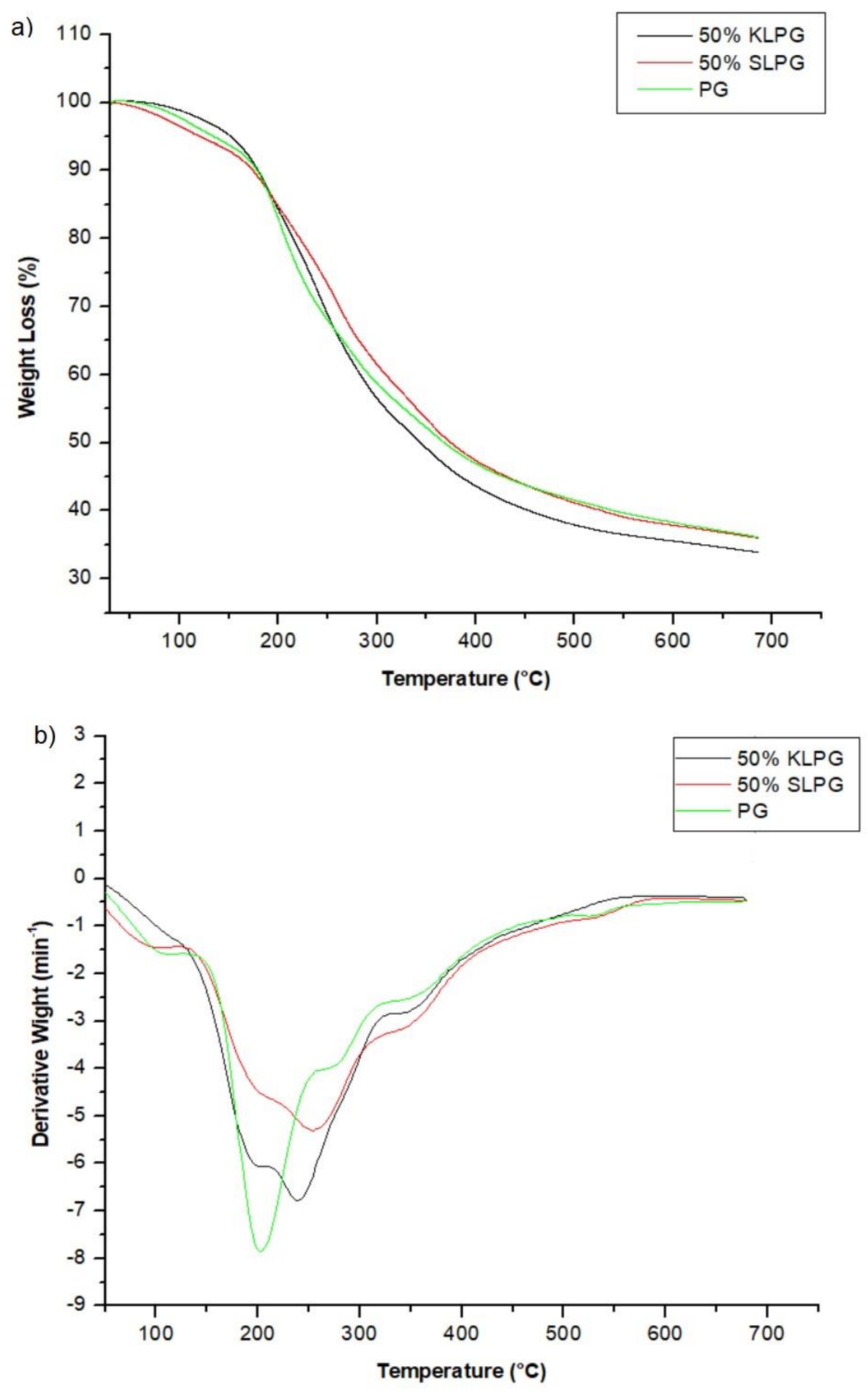

Fig. 6. a) TG and b) DTG curves of $50 \% \mathrm{KLPG}, 50 \%$ SLPG, and PG resins 


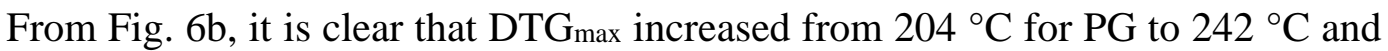
$258{ }^{\circ} \mathrm{C}$ for $50 \% \mathrm{KLPG}$ and SLPG, respectively. The results suggested an improvement to the thermal performance of LPG due to the cross-linking between lignin and glyoxal, which increased the molecular weight of lignin. In addition, the decomposition rate reduced for LPG resins compared to PG, which could be due to the reaction degree variation for crosslinking with glyoxal (Wang et al. 2018). The residue of KLPG and SLPG samples at around $600{ }^{\circ} \mathrm{C}$ were $17.4 \%$ and $20.3 \%$, respectively, which are lower than the residue of PG $(28.6 \%)$. This can be ascribed to the free volume in LPG that leads to a full degradation. This could be attributed to the increase of the side chain on C3 and C5 positions due to glyoxal addition (Glasser and Jain 1993; Wang et al. 2018).

\section{Physico-mechanical Analysis of Wood Adhesives}

At replacement levels from 10 up to $50 \%$ kraft and soda lignin $(10 \%, 30 \%$, and $50 \%$ LPG), the mechanical strength were equal or higher than the commercial resin PF. The highest tensile strength (65.3 MPa), elastic modulus (581.3 MPa), and elongation at break $(15.5 \%)$ were represented by $50 \%$ KLPG. In contrast, the commercial resin (PF) recorded lower mechanical properties values than 50\% KLPG (tensile strength: 58.6 MPa, elastic modulus: MPa, and elongation at break: 13.1\%) (Table 7).

Table 7. Physico-mechanical Analysis of PG, PF, KLPG, and SLPG Adhesives

\begin{tabular}{|c|c|c|c|}
\hline Resin & $\begin{array}{c}\text { Tensile Strength } \\
(\mathrm{MPa})\end{array}$ & $\begin{array}{c}\text { Elastic Modulus } \\
(\mathrm{MPa})\end{array}$ & $\begin{array}{c}\text { Elongation at } \\
\text { Break } \\
(\%)\end{array}$ \\
\hline $\mathrm{PF}$ & $58.57 \pm 0.91$ & $551.43 \pm 1.07$ & $13.14 \pm 0.51$ \\
\hline PG & $63.53 \pm 0.78$ & $604.68 \pm 1.10$ & $12.68 \pm 0.03$ \\
\hline $10 \%$ SLPG & $43.36 \pm 1.01$ & $427.16 \pm 1.21$ & $13.41 \pm 1.02$ \\
\hline $30 \%$ SLPG & $54.94 \pm 1.22$ & $530.13 \pm 1.02$ & $14.46 \pm 0.70$ \\
\hline $50 \%$ SLPG & $61.02 \pm 0.75$ & $532.18 \pm 0.95$ & $15.74 \pm 0.32$ \\
\hline $10 \%$ KLPG & $58.34 \pm 0.98$ & $501.65 \pm 1.06$ & $14.57 \pm 0.21$ \\
\hline $30 \%$ KLPG & $59.63 \pm 1.02$ & $565.86 \pm 1.12$ & $14.26 \pm 1.01$ \\
\hline $50 \%$ KLPG & $65.30 \pm 0.88$ & $581.32 \pm 0.87$ & $15.46 \pm 0.34$ \\
\hline
\end{tabular}

It was clear that at $50 \%$ kraft lignin substitution, the cross-linking formation was at the highest level. This may be due to the presence of phenolic-OH in lignin molecules. As a result, KL effectively substituted for phenol in LPG resins, while glyoxal was able to entirely substitute for formaldehyde (Hussin et al. 2018). From the results illustrated in Fig. 7, 50\% KLPG has the highest tensile strength due to the highest amount of phenolic groups as reported in ${ }^{13} \mathrm{C}$ NMR analysis. Lignin-phenol-glyoxal condensation takes place through electrophilic substitution of glyoxal in G-type lignin-free sites (C5 and C3 positions). Furthermore, the high amount of phenolic-OH groups in the structure of lignin provides active positions at the aromatic ring for glyoxal reaction (Thring et al. 1990; Tejado et al. 2007). The relatively higher amount of phenolic-OH in kraft lignin compared to soda lignin indicates the higher amount of aromatic rings. As a result, during the condensation reaction, the molecular weight, solid content, and viscosity of the resol resin increase so that they can be used as wood adhesive, as shown in the physico-chemical results. During the curing process, methylol groups are transformed from low molecular weight materials into a highly branched network of LPG resin using temperature around $140{ }^{\circ} \mathrm{C}$. The structure of the resin in this stage is more complex resulting from additional condensation reaction (Siddiqui 2013). 
Overall, 50\% KLPG demonstrated durable bonding characteristics in comparison to the commercial PF adhesives. The 50\% KLPG adhesive showed that it is possible to produce an ecofriendly wood adhesive from date palm fronds lignin and glyoxal as phenol and formaldehyde substituents, respectively.

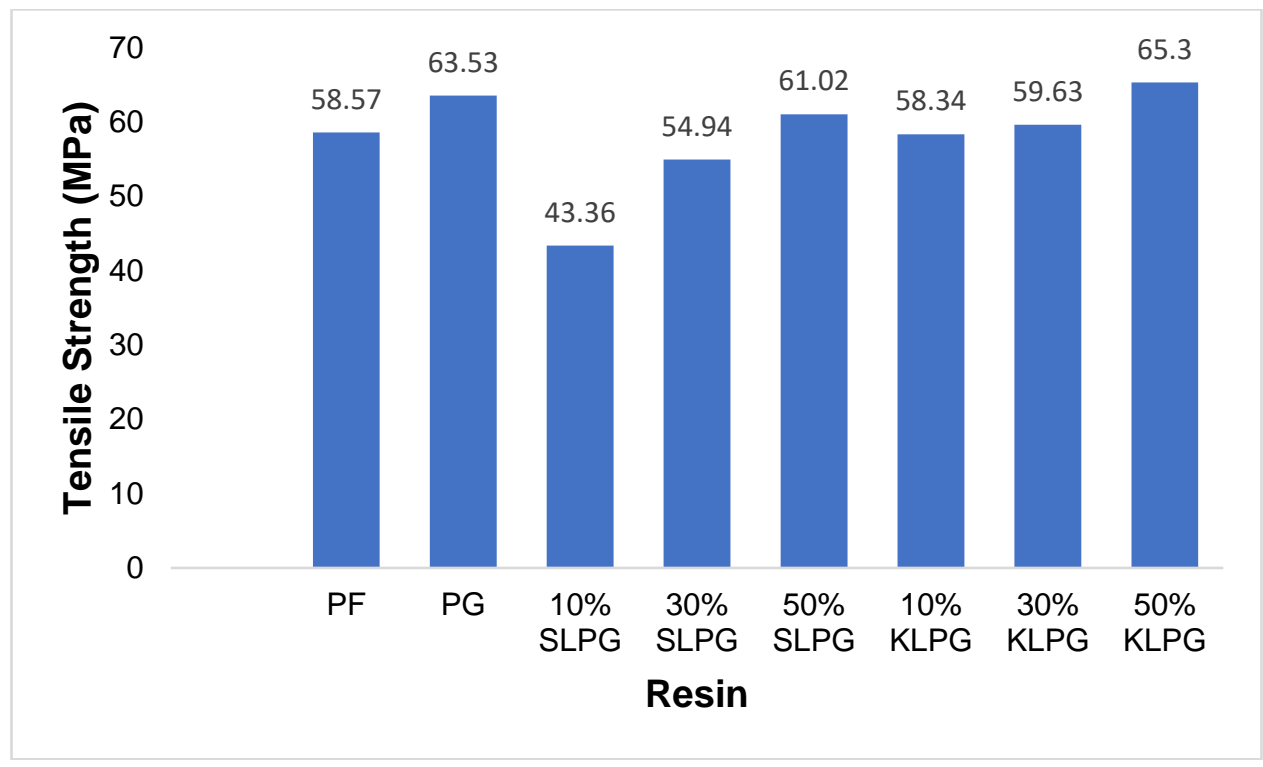

Fig. 7. Tensile strength of PG, LPG, and PF adhesives

\section{CONCLUSIONS}

1. The characteristics of the extracted date palm fronds' lignin demonstrated that both kraft and soda lignin can serve as a partial substituent of phenol in lignin phenol glyoxal resins

2. Kraft and soda lignin from date palm fronds (DPF) demonstrated thermal stability, showing that the maximum of the differential thermogravimetric (DTG $\mathrm{Dax}_{\max }$ ) curve for kraft and soda lignin was 375 and $381{ }^{\circ} \mathrm{C}$, respectively.

3. In terms of physicochemical properties, 50\% kraft lignin phenol glyoxal (KLPG) adhesive presented the highest solid content $(40 \%)$, viscosity $(0.165 \mathrm{~Pa}-\mathrm{s})$, and the shortest gel time (140 s) in comparison with $50 \%$ soda lignin phenol glyoxal (SLPG) and phenol glyoxal (PG) resins.

4. The physico-mechanical properties showed that 50\% KLPG resin has the highest tensile strength in dry conditions (65.30 MPa) compared to SLPG and PF resins. In conclusion, 50\% KLPG resin can substitute the commercial PF adhesives as a stronger and non-toxic green wood adhesive.

\section{ACKNOWLEDGMENTS}

This work was supported by Universiti Sains Malaysia (Penang, Malaysia) through USM Research University Incentive Grant - 1001/PKIMIA/8011077. 


\section{REFERENCES CITED}

Aziz, N. A., Latip, A. F. A., Peng, L. C., Latif, N. H. A., Brosse, N., Hashim, R., and Hussin, M. H. (2019). "Reinforced lignin-phenol-glyoxal (LPG) wood adhesives from coconut husk," Int. J. Biol. Macromol. 141, 185-196. DOI:

10.1016/j.ijbiomac.2019.08.255

Ballerini, A., Despres, A., and Pizzi, A. (2005). "Non-toxic, zero emission tannin-glyoxal adhesives for wood panels," Holz. Roh. Werkst. 63(6), 477-478. DOI:

10.1007/s00107-005-0048-X

Capanema, E. A., Balakshin, M., and Kadla, J. (2004). "A comprehensive approach for quantitative lignin characterization by NMR spectroscopy," J. Agr. Food Chem. 52(7), 1850-1860. DOI: 10.1021/jf035282b

Danielson, B., and Simonson, R. (1998). "Kraft lignin in phenol resin. Part 1. Partial replacement of phenol by kraft lignin in phenol formaldehyde adhesives for plywood," J. Adhes. Sci. Technol. 12(9), 923-939. DOI: 10.1163/156856198X00542

El Mansouri, N. E., Yuan, Q., and Huang, F. (2011). "Study of chemical modification of alkaline lignin by the glyoxalation reaction," BioResources 6(4), 4523-4536.

Faris, A. H., Rahim, A. A., Ibrahim, M. N. M., Hussin, M. H., Alkurdi, A. M., and Salehabadi, A. (2017). "Investigation of oil palm based kraft and auto-catalyzed organosolv lignin susceptibility as a green wood adhesives," Int. J. Adhes. Adhes. 74, 115-122. DOI: 10.1016/j.ijadhadh.2017.01.006

Foyer, G., Chanfi, B. H., Virieux, D., David, G., and Caillol, S. (2016a). "Aromatic dialdehyde precursors from lignin derivatives for the synthesis of formaldehyde-free and high char yield phenolic resins," Eur. Polym. J. 77, 65-74. DOI: 10.1016/j.eurpolymj.2016.02.018

Foyer, G., Chanfi, B. H., Boutevin, B., Caillol, S., and David, G. (2016b). "New method for the synthesis of formaldehyde-free phenolic resins from lignin-based aldehyde precursors," Eur. Polym. J. 74, 296-309. DOI: 10.1016/j.eurpolymj.2015.11.036

García, A., Toledano, A., Serrano, L., Eguiés, I., Alriols, M. G., Marín, F., and Labidi, J. (2009). "Characterization of lignins obtained by selective precipitation," Sep. Purif. Technol. 68(2), 193-198. DOI: 10.1016/j.seppur.2009.05.001

Glasser, W. G., and Jain, R. K. (1993). "Lignin derivatives. I. Alkanoates," Holzforschung 47(3), 225-233. DOI: 10.1515/hfsg.1993.47.3.225

Hoareau, W., Trindade, W., Siegmund, B., Castellan, A., and Frollini, E. (2004). "Sugar cane bagasse and curaua lignins oxidized by chlorine dioxide and reacted with furfuryl alcohol: Characterization and stability," Polym. Degrad. Stabil. 86(3), 567576. DOI: 10.1016/j.polymdegradstab.2004.07.005

Horwath, W. (2015). "Carbon cycling: The dynamics and formation of organic matter," in: Soil Microbiology, Ecology and Biochemistry ( ${ }^{\text {th }}$ ed.), E. A. Paul (ed.), Academic Press, Fort Collins, CO, USA.

Hussin, M. H., Rahim, A. A., Ibrahim, M. N. M., and Brosse, N. (2013).

"Physicochemical characterization of alkaline and ethanol organosolv lignins from oil palm (Elaeis guineensis) fronds as phenol substitutes for green material applications," Ind. Crop. Prod. 49, 23-32. DOI: 10.1016/j.indcrop.2013.04.030

Hussin, M. H., Zhang, H. H., Aziz, N. A., Samad, N. A., Faris, A. H., Ibrahim, M. N. M., Iqbal, A., Latip, A. F. A., and Haafiz, M. K. M. (2017). "Preparation of environmental friendly phenol-formaldehyde wood adhesive modified with kenaf lignin,” J. Appl. Sci. 6(4), 409-418. DOI: 10.1016/j.bjbas.2017.06.004 
Hussin, M. H., Samad, N. A., Latif, N. H. A., Rozuli, N. A., Yusoff, S. B., Gambier, F., and Brosse, N. (2018). "Production of oil palm (Elaeis guineensis) fronds ligninderived non-toxic aldehyde for eco-friendly wood adhesive," Int. J. Biol. Macromol. 113, 1266-1272. DOI: 10.1016/j.ijbiomac.2018.03.048

Hussin, M. H., Aziz, A. A., Iqbal, A., Ibrahim, M. N. M., and Latif, N. H. A. (2019). "Development and characterization novel bio-adhesive for wood using kenaf core (Hibiscus cannabinus) lignin and glyoxal," Int. J. Biol. Macromol. 122, 713-722. DOI: $10.1016 /$ j.ijbiomac.2018.11.009

IARC Working Group on the Evaluation of Carcinogenic Risks to Humans (2006). Formaldehyde, 2-Butoxyethanol and 1-Tert-butoxypropan-2-ol, IARC Monographs on the Evaluation of Carcinogenic Risks to Humans (Vol. 88), International Agency for Research on Cancer, World Health Organization, Lyon, France.

Ibrahim, M. N. M., Ghani, A. M., and Nen, N. (2007). "Formulation of lignin phenol formaldehyde resins as a wood adhesive," Malaysian J. Anal. Sci. 11(1), 213-218.

Ibrahim, M. M., Agblevor, F., and El-Zawawy, W. K. (2010). "Isolation and characterization of cellulose and lignin from steam-exploded lignocellulosic biomass," BioResources 5(1), 397-418. DOI:10.15376/biores.5.1.397-418

Ibrahim, M. N. M., Zakaria, N., Sipaut, C. S., Sulaiman, O., and Hashim, R. (2011). "Chemical and thermal properties of lignins from oil palm biomass as a substitute for phenol in a phenol formaldehyde resin production," Carbohyd. Polym. 86(1), 112119. DOI: $10.1016 / j$.carbpol.2011.04.018

JIS A 5908 (2003). "Particleboards," Japanese Standards Association, Tokyo, Japan.

Lenghaus, K., Qiao, G. G., and Solomon, D. H. (2001). "The effect of formaldehyde to phenol ratio on the curing and carbonisation behaviour of resole resins," Polym. J. 42(8), 3355-3362. DOI: 10.1016/S0032-3861(00)00710-2

Mallaki, M., and Fatehi, R. (2014). "Design of a biomass power plant for burning date palm waste to cogenerate electricity and distilled water," Renew. Energ. 63, 286-291. DOI: 10.1016/j.renene.2013.09.036

Mansouri, N., Pizzi, A., and Salvado, J. (2007). "Lignin-based polycondensation resins for wood adhesives," J. Appl. Polym. Sci. 103(3), 1690-1699. DOI: 10.1002/app. 25098

McGregor, D., Bolt, H., Cogliano, V., and Richter-Reichhelm, H. B. (2006). "Formaldehyde and glutaraldehyde and nasal cytotoxicity: Case study within the context of the 2006 IPCS human framework for the analysis of a cancer mode of action for humans," Crit. Rev. Toxicol. 36(10), 821-835. DOI: 10.1080/10408440600977669

Monni, J., Alvila, L., and Pakkanen, T. T. (2007). "Structural and physical changes in phenol-formaldehyde resol resin, as a function of the degree of condensation of the resol solution," Ind. Eng. Chem. Res. 46(21), 6916-6924. DOI: 10.1021/ie070297a

Moubarik, A., Barba, F. J., and Grimi, N. (2015). "Understanding the physicochemical properties of olive kernel to be used as a potential tool in the development of phenolformaldehyde wood adhesive," Int. J. Adhes. Adhes. 61, 122-126. DOI: 10.1016/j.ijadhadh.2015.06.003

Nadji, H., Diouf, N., Benaboura, A., Bedard, Y., Riedl, B., and Stevanovic, T. (2009). "Comparative study of lignins isolated from Alfa grass (Stipa tenacissima L.)," Bioresource Technol. 100(14), 3585-3592. DOI: 10.1016/j.biortech.2009.01.074

Nasser, R., Salem, M. Z. M., Hiziroglu, S., Al-Mefarrej, H., Mohareb, A., Alam, M., and Aref, I. (2016). "Chemical analysis of different parts of date palm (Phoenix 
dactylifera L.) using ultimate, proximate and thermo-gravimetric techniques for energy production," Energies 9(5), Article number 374. DOI: 10.3390/en9050374

Norström, E., Fogelström, L., Nordqvist, P., Khabbaz, F., and Malmström, E. (2014). "Gum dispersions as environmentally friendly wood adhesives," Ind. Crop. Prod. 52, 736-744. DOI: 10.1016/j.indcrop.2013.12.001

Ramires, E. C., Megiatto, Jr., J. D., Gardrat, C., Castellan, A., and Frollini, E. (2010). "Biobased composites from glyoxal-phenolic resins and sisal fibers," Bioresource Technol. 101(6), 1998-2006. DOI: 10.1016/j.biortech.2009.10.005

Sahoo, S., Seydibeyoğlu, M. Ö., Mohanty, A. K., and Misra, M. (2011). "Characterization of industrial lignins for their utilization in future value added applications," Biomass Bioenerg. 35(10), 4230-4237. DOI: 10.1016/j.biombioe.2011.07.009

Santiago-Medina, F., Foyer, G., Pizzi, A., Caillol, S., and Delmotte, L. (2016). "Ligninderived non-toxic aldehydes for ecofriendly tannin adhesives for wood panels," Int. J. Adhes. Adhes. 70, 239-248. DOI: 10.1016/j.ijadhadh.2016.07.002

Siddiqui, H. (2013). Production of Lignin-based Phenolic Resin Using De-polymerized Kraft Lignin and Process Optimization, Master's Thesis, The University of Western Ontario, London, Canada.

Sun, R., Tomkinson, J., and Jones, G. L. (2000). "Fractional characterization of ash-AQ lignin by successive extraction with organic solvents from oil palm EFB fibre," Polym. Degrad. Stabil. 68(1), 111-119. DOI: 10.1016/S0141-3910(99)00174-3

Sun, S. N., Li, M. F., Yuan, T. Q., Xu, F., and Sun, R. C. (2012). "Sequential extractions and structural characterization of lignin with ethanol and alkali from bamboo (Neosinocalamus affinis)," Ind. Crop. Prod. 37(1), 51-60. DOI: 10.1016/j.indcrop.2011.11.033

TAPPI T203 cm-09. (2009). "Alpha-, Beta- and Gamma-Cellulose in Pulp,” Technical Association of the Pulp and Paper Industry, Atlanta, GA, USA.

TAPPI T222 om-02. (2006). “Acid-insoluble lignin in wood and pulp,” Technical Association of the Pulp and Paper Industry, Atlanta, GA, USA.

TAPPI T650 cm-15. (2015). "Solids content of black liquor," Technical Association of the Pulp and Paper Industry, Atlanta, GA, USA.

Tejado, A., Pena, C., Labidi, J., Echeverria, J. M., and Mondragon, I. (2007). "Physicochemical characterization of lignins from different sources for use in phenolformaldehyde resin synthesis," Bioresource Technol. 98(8), 1655-1663. DOI: 10.1016/j.biortech.2006.05.042

Thring, R. W., Chornet, E., Bouchard, J., Vidal, P. F., and Overend, R. P. (1990). "Characterization of lignin residues derived from the alkaline hydrolysis of glycol lignin," Can. J. Chem. 68(1), 82-89. DOI: 10.1139/v90-017

Thring, R. W., Chornet, E., Bouchard, J., Vidal, P. F., and Overend, R. P. (1991). "Evidence for the heterogeneity of glycol lignin," Ind. Eng. Chem. Res. 30(1), 232240. DOI: 10.1021/ie00049a036

Trick, K. A., and Saliba, T. E. (1995). "Mechanisms of the pyrolysis of phenolic resin in a carbon/phenolic composite," Carbon 33(11), 1509-1515. DOI: 10.1016/00086223(95)00092-R

Trosa, A., and Pizzi, A. (1998). "Industrial hardboard and other panels binder from waste lignocellulosic liquors/phenol-formaldehyde resins," Holz. Roh. Werkst. 56(4), 229233. DOI: $10.1007 / \mathrm{s} 001070050307$ 
Váquez-Torres, H., Canché-Escamilla, G., and Cruz-Ramos, C. A. (1992). "Coconut husk lignin. I. Extraction and characterization,” J. Appl. Polym. Sci. 45(4), 633-644. DOI: 10.1002/app.1992.070450410

Wang, S., Yu, Y., and Di, M. (2018). "Green modification of corn stalk lignin and preparation of environmentally friendly lignin-based wood adhesive," PolymersBasel 10(6), Article no. 631. DOI: 10.3390/polym10060631

$\mathrm{Wu}, \mathrm{G}$. (1997). "Low-volatile and strongly basic tertiary amino alcohols as catalyst for the manufacture of improved phenolic resins," U. S. Patent No. 5623032.

Younesi-Kordkheili, H. (2019). "Ionic liquid modified lignin-phenol-glyoxal resin: A green alternative resin for production of particleboards," J. Adhesion 95(12), 10751087. DOI: 10.1080/00218464.2018.1471994

Younesi-Kordkheili, H., and Pizzi, A. (2019). "Some of physical and mechanical properties of particleboard panels bonded with phenol-lignin-glyoxal resin," $J$. Adhesion 1-11. DOI: 10.1080/00218464.2019.1600405

Zhang, W., Ma, Y., Wang, C., Li, S., Zhang, M., and Chu, F. (2013). "Preparation and properties of lignin-phenol-formaldehyde resins based on different biorefinery residues of agricultural biomass," Ind. Crop. Prod. 43, 326-333. DOI: 10.1016/j.indcrop.2012.07.037

Article submitted: February 19, 2021; Peer review completed: April 11, 2021; Revised version received and accepted: April 21, 2021; Published: April 26, 2021.

DOI: $10.15376 /$ biores.16.2.4106-4125 